deducing from Articles 25, 33(2), 34, 39, 48, 49, 92, and 94 that, for example, human rights are now subject to international jurisdiction despite Article 2(7) when the patterns of behavior include the killing of Indian populations in South America, the jailing and torture of political opponents in dozens of countries, thirty years of apartheid in South Africa, the current excesses in Ethiopia and Cambodia, and the tragicomedy of Uganda? If Professor Paust wishes to stack his list of rarely used articles against such facts and ignore the inability of the international legal system to control them, then it is he, and not I, who's approach is, in his words, "hardly realistic or useful."

\title{
To The Editor-In-Chief
}

J. S. WATSON

In reviewing Russian and Soviet Law: An Annotated Catalogue of Reference Works, Legislation, Court Reports, Serials, and Monographs on Russian and Soviet Law, by William E. Butler, in the July issue of the Journal (71 AJIL 578 (1977)), I mistakenly gave the number of titles covered as 250; the correct figure is 1200 .

JOHN N. HAZARD

\section{Statement of Ownership, Management and Circulation}

(Act of August 12, 1970; Sec. 3685, Title 39, U.S. Code)

Filed September 1977. American Journal of International Law (issued quarterly, January, April, July, October), Prince \& Lemon Streets, Lancaster, Pennsylvania 17604. Published by American Society of International Law, 2223 Massachusetts Avenue, N.W., Washington, D.C. 20008. Editor-in-Chief, Richard R. Baxter, Harvard Law School, Cambridge, Mass. 02138. Assistant Editor, Anne P. Simons. Owner, American Society of International Law. Average number of copies per issue, last 12 months: total printed, 10,012; paid circulation, 8,064; mail subscriptions, 8,064; total paid circulation, 8,064 ; free distribution, 158; total distribution, 8,222 ; office use, left over, unaccounted, spoiled after printing, 1,790. For single issue nearest to filing date: total printed, 10,192; paid circulation, 7,853; mail subscriptions, 7,853 ; total paid circulation, 7,853 ; free distribution, 158; total distribution, 8,011; office use, left over, unaccounted, spoiled after printing, 2,181. I certify that the statements made by me are correct and completeAnne P. Simons. 